Article

\title{
A Study on Elevated Concentrations of Submicrometer Particles in an Urban Atmosphere
}

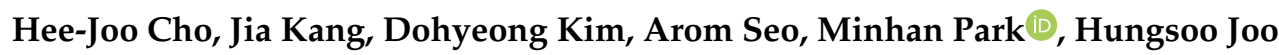 \\ and Kihong Park*
}

National Leading Research Laboratory (Aerosol Technology and Monitoring Laboratory), School of Environmental Science and Engineering, Gwangju Institute of Science and Technology (GIST), 261 Cheomdan-Gwagiro, Buk-gu, Gwangju 61005, Korea; cheejoo@gist.ac.kr (H.J.C.) rahaim@naver.com (J.K.); KDH8601@gmail.com (D.K.); aromseo@sisul.or.kr (A.S.); parkmh@gist.ac.kr (M.P.); hjoo@gist.ac.kr (H.J.)

* Correspondence: kpark@gist.ac.kr; Tel.: +82-62-715-3279; Fax: +82-62-715-2434

Received: 14 August 2018; Accepted: 4 October 2018; Published: 10 October 2018

\begin{abstract}
Mass concentrations of chemical constituents (organics, nitrate, sulfate, ammonium, chloride, and black carbon (BC)) and the number size distribution of submicrometer particles in the ambient atmosphere were continuously measured in urban Gwangju, Korea, during the Megacity Air Pollution Studies (MAPS)-Seoul campaign. Organics $\left(9.1 \mu \mathrm{g} / \mathrm{m}^{3}\right)$ were the most dominant species, followed by sulfate $\left(4.7 \mu \mathrm{g} / \mathrm{m}^{3}\right)$, nitrate $\left(3.2 \mu \mathrm{g} / \mathrm{m}^{3}\right)$, ammonium $\left(2.6 \mu \mathrm{g} / \mathrm{m}^{3}\right)$, and BC $\left(1.3 \mu \mathrm{g} / \mathrm{m}^{3}\right)$ in submicrometer particles (particulate matter less than $1 \mu \mathrm{m}\left(\mathrm{PM}_{1}\right)$ ). The potential source regions of the sulfate were located in the South and East regions of China and South and East regions of Korea, while local sources were responsible for the elevated BC concentration. Diurnal variation showed that concentrations of organics, nitrate, ammonium, chloride, and BC decreased with increasing mixing layer and wind speed (dilution effect), while sulfate and oxidized organics increased possibly due to their strong photochemical production in the afternoon. During the campaign, an elevated mass concentration of $\mathrm{PM}_{1}\left(\mathrm{PM}_{1}\right.$ event) and number concentration (nanoparticle formation (NPF) event) were observed (one $\mathrm{PM}_{1}$ event and nine NPF events out of 28 days). The $\mathrm{PM}_{1}$ event occurred with Western and Southwestern air masses with increasing sulfate and organics. Long-range transported aerosols and stagnant meteorological conditions favored the elevated mass concentration of submicrometer particles. Most of the NPF events took place between 10:00 and 14:00, and the particle growth rates after the initial nanoparticle formation were $7.2-11.0 \mathrm{~nm} / \mathrm{h}$. The times for increased concentration of nanoparticles and their growth were consistent with those for elevated sulfate and oxidized organics in submicrometer particles under strong photochemical activity.
\end{abstract}

Keywords: aerosols; black carbon; new particle formation; MAPS-Seoul 2015; East Asia

\section{Introduction}

Fine particulate matter (PM) in the ambient atmosphere is of current interest due to its effects on climate change (radiation balance and cloud formation) [1] and human health [2-4]. Due to multiple sources and formation pathways, chemical constituents in fine PM differ significantly among locations and times. Fine PM is directly emitted from various sources (primary aerosols) and/or produced by gas-to-particle conversion processes (secondary aerosols) and rapidly experiences the aging process (condensation, coagulation, oxidation, cloud processing, and so on), leading to different chemical and mixing states from the original particles. Additionally, the existence of ultrafine particles $(<100 \mathrm{~nm})$ in the ambient atmosphere have often been observed due to direct emissions from combustion sources and nanoparticle formation (NPF) with subsequent rapid growth [5-7]. Due to the rapid dynamic process of fine PM, real-time measurements of their physical and chemical properties are essential 
to better understand their sources and formation pathways when elevated PM mass and number concentrations are observed.

Long-range transport (LTP) aerosols play an important role in the elevated mass concentration of submicrometer particles in East Asia [8-10]. It has often been observed that the chemical constituents in PM less than $1 \mu \mathrm{m}\left(\mathrm{PM}_{1}\right)$ or $2.5 \mu \mathrm{m}\left(\mathrm{PM}_{2.5}\right)$ were dependent on the types of long-range transported air mass arriving at sites $[7,8,11,12]$. Sulfate-dominant and organic-dominant LTP events have been found with different air mass types in Korea [8]. A significant number of elevated $\mathrm{PM}_{2.5}$ concentrations in Korea during winter and spring seasons have been explained by long-range transported aerosols [13].

Nanoparticle formation significantly contributes to an enhanced number concentration of submicrometer particles in the ambient atmosphere [12,14]. NPF events have often been observed in many locations worldwide including East Asia [11,12,15]. It has been reported that the low surface area of pre-existing particles and high growth of initial clusters favors NPF in the ambient atmosphere [16].

In this study, mass concentrations of organics, nitrate, sulfate, ammonium, chloride, and black carbon (BC) of submicrometer particles and the number size distribution of particles from $10 \mathrm{~nm}$ to $25 \mu \mathrm{m}$ in an urban atmosphere (Gwangju, Korea) were continuously measured during the period of the Megacity Air Pollution Studies (MAPS)-Seoul 2015 campaign (18 May 2015-14 June 2015). Air mass backward trajectory analysis, residence time analysis (RTA), and potential source contribution function (PSCF) methods were applied to examine the effects of long-range transported aerosols on elevated $\mathrm{PM}_{1}$ and their chemical constituents, as well as to infer possible geographic source regions of the long-range transported aerosols. Number size distribution data were used to examine NPF in relation to the chemical composition of submicrometer particles and meteorological parameters.

\section{Experimental Section}

The ambient aerosol measurements were conducted at an urban Gwangju site during the period of the MAPS-Seoul 2015 campaign (18 May 2015-14 June 2015). As shown in Figure 1, the sampling site is under the influence of multiple local aerosol sources such as residential/commercial areas $(\sim 0.6 \mathrm{~km}$ away from the site), highways ( $1.5 \mathrm{~km}$ away from the site), a small industrial area $(\sim 1.5 \mathrm{~km}$ away from the site), and an agricultural area $(\sim 0.8 \mathrm{~km}$ away from the site) $[5,17]$. The site is also influenced by short-range transported aerosols from a petrochemical industrial complex and steel works located $\sim 90 \mathrm{~km}$ Southeast of the site and long-range transported aerosols from China, North Korea, and Mongolia in East Asia.

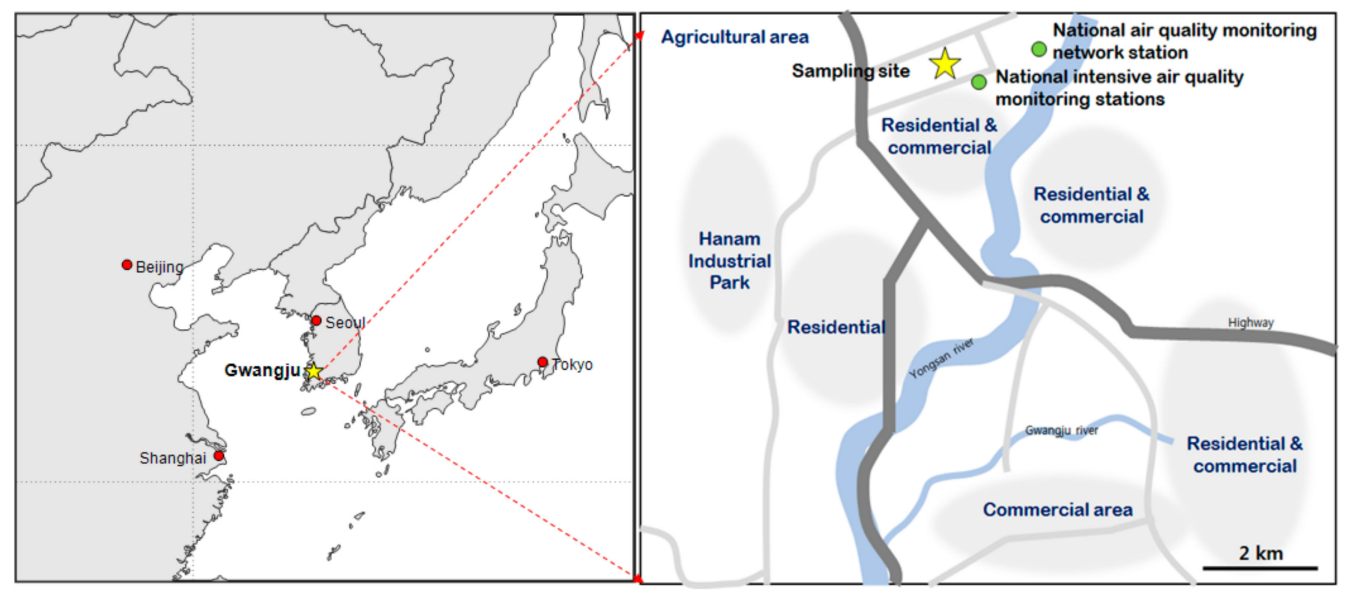

Figure 1. Locations of the aerosol measurement site and national monitoring stations.

Table 1 summarizes the measured parameters at the sampling site and nearby national monitoring sites. Chemical constituents (organics, nitrate, sulfate, ammonium, and chloride) of non-refractory submicrometer particles were measured in real time using an aerosol mass spectrometer (AMS) (Aerodyne, Billerica, MA, USA). A detailed description of the AMS is described elsewhere [13,17-19]. 
Briefly, the ambient air was sampled into the AMS through a 100- $\mu$ m diameter critical orifice with a flow rate of 0.07 liters per minute $(\mathrm{lpm})$. The aerodynamic lens system focused submicrometer particles into the vaporization and ionization region. Particles were vaporized on the V-shaped tip of the vaporizer at the temperature of $600{ }^{\circ} \mathrm{C}$, then the vapors were ionized by electron impaction $(70 \mathrm{eV})$. The produced ions were detected with a quadrupole mass spectrometer. The collection efficiency of ambient particles in the AMS was assumed to be 50\% [20]. Calibrations of the electron multiplier gain value, ionization efficiency, and particle size of the AMS were conducted using the previous methods in Jimenez et al. (2003) [21]. Ammonium nitrate particles (300 nm) were used for the ionization efficiency calibration, which was conducted every week. Organic aerosols (OAs) were further classified into hydrocarbon-like OAs (HOAs) and oxygenated OAs (OOAs) by positive matrix factorization (PMF) analysis $[13,22]$. The HOAs are related to primary OAs produced from combustion sources (the HOAs are often correlated with combustion tracers such as $\mathrm{CO}$, elemental carbon (EC), and $\mathrm{NO}_{\mathrm{x}}$ ), while the OOAs are related to secondary organic aerosols (SOAs) produced by photochemical activity [23]. The number of factors was determined based on dissimilarities in the average mass spectra $(\mathrm{m} / \mathrm{z} 43$, 44,55 , and 57), Q/Q $\mathrm{Qxp}_{\text {, }}$ and temporal variation of the factors [22,24]. The concentration of BC was measured with an Aethalometer (AE51, Magee Scientific, USA) every 5 min with a flow rate of $0.2 \mathrm{lpm}$. The Aethalometer measures BC concentration by measuring the attenuation of the transmission of light through the collected samples on the filter [25]. The filter was changed every day [26].

Table 1. Summary of the measured parameters and instruments during the sampling period.

\begin{tabular}{|c|c|c|}
\hline Measured Parameters & Instruments & Sampling Period \\
\hline $\mathrm{PM}_{2.5}$ mass concentration ${ }^{\mathrm{a}}$ & BAM-1020 (Met One Instruments, USA) & 18 May 2015-14 June 2015 \\
\hline \multicolumn{3}{|l|}{ Chemical constituents in $\mathrm{PM}_{1}$} \\
\hline $\begin{array}{l}\text { Sulfate, Nitrate, Ammonium, } \\
\text { Chloride, Organics }\end{array}$ & AMS (Aerodyne, USA) & 18 May 2015-14 June 2015 \\
\hline $\mathrm{BC}$ & Aethalometer (AE-51, Magee Scientific, USA) & 18 May 2015-7 June 2015 \\
\hline \multicolumn{3}{|l|}{ Number size distribution } \\
\hline $10-420 \mathrm{~nm}$ & NanoScan SMPS (3910, TSI, USA) & 18 May 2015-14 June 2015 \\
\hline $11-608 \mathrm{~nm}$ & $\begin{array}{l}\text { DMPS (DMA (3081, TSI, USA) and CPC } \\
(3022 a, \text { TSI, USA) }\end{array}$ & 18 May 2015-14 June 2015 \\
\hline $\begin{array}{l}0.3-20 \mu \mathrm{m} \\
\text { Gases a }\end{array}$ & OPC (1.108, Grimm, Germany) & 18 May 2015-14 June 2015 \\
\hline $\mathrm{CO}$ & CO analyzer (300E, Teledyne API., USA), & 18 May 2015-14 June 2015 \\
\hline $\mathrm{SO}_{2}$ & $\mathrm{SO}_{2}$ Analyzer (100E, Teledyne API., USA) & 18 May 2015-14 June 2015 \\
\hline $\mathrm{NO}_{2}$ & $\mathrm{NO}_{x}$ Analyzer (200E, Teledyne API., USA) & 18 May 2015-14 June 2015 \\
\hline $\mathrm{O}_{3}$ & $\mathrm{O}_{3}$ Analyzer (400E, Teledyne API., USA) & 18 May 2015-14 June 2015 \\
\hline \multicolumn{3}{|l|}{ Meteorological parameters } \\
\hline Wind speed ${ }^{\mathrm{b}}$ & $\begin{array}{l}\text { Wind speed sensor (JY-WS161C, Jinyang } \\
\text { Industrial, Korea) }\end{array}$ & 18 May 2015-14 June 2015 \\
\hline Wind direction ${ }^{b}$ & $\begin{array}{l}\text { Wind direction sensor (JY100829, Jinyang } \\
\text { Industrial, Korea) }\end{array}$ & 18 May 2015-14 June 2015 \\
\hline Precipitation ${ }^{b}$ & $\begin{array}{l}\text { Rain Gauge (JY100097-2, Jinyang Industrial, } \\
\text { Korea) }\end{array}$ & 18 May 2015-14 June 2015 \\
\hline Temperature ${ }^{b}$ & $\begin{array}{l}\text { Temperature sensor (JY100829, Jinyang } \\
\text { Industrial, Korea) }\end{array}$ & 18 May 2015-14 June 2015 \\
\hline Relative humidity $^{\mathrm{c}}$ & $\begin{array}{l}\text { Thermo-hygrometer (HTP-20, Wellbian } \\
\text { System, Korea) }\end{array}$ & 18 May 2015-14 June 2015 \\
\hline Solar radiation ${ }^{c}$ & $\begin{array}{l}\text { Pyrheliometer (CMP-21, Kipp \& Zonen, } \\
\text { Netherlands) }\end{array}$ & 18 May 2015-14 June 2015 \\
\hline
\end{tabular}

The number size distribution of particles from $10 \mathrm{~nm}$ to $25 \mu \mathrm{m}$ was measured using a NanoScan-scanning mobility particle sizer (SMPS) (3910, TSI, USA), a differential mobility particle 
sizer (DMPS) consisting of a differential mobility analyzer (DMA) (3081, TSI, USA), a condensation particle counter (CPC) (TSI 3022a, TSI, USA), and an optical particle counter (OPC) (1.108, Grimm, Germany). The scan times for the NanoScan-SMPS, DMPS, and OPC were $1 \mathrm{~min}, 5 \mathrm{~min}$, and 1 min, respectively. The number size distributions from NanoScan-SMPS (10-133 nm) and DMPS (146-608 nm) were combined together. The combined size distribution was shown in this paper. Size-dependent transport losses of particles through tubes in the NanoScan-SMPS or DMPS were corrected theoretically [27]. The mode diameter was estimated by fitting the number size distribution data into a Gaussian distribution. The number of modes (mono-modal or bi-modal) was selected from the best fit results.

The $\mathrm{PM}_{2.5}$ mass concentration, gaseous components, and meteorological parameters were obtained from the nearest air quality monitoring network stations. Temperature, wind speed, wind direction, precipitation, solar radiation, and relative humidity $(\mathrm{RH})$ were obtained from an automatic weather station (AWS) and the automated surface observation system (ASOS) operated by the Korea Meteorology Administration (KMA).

A 48-h air mass backward trajectory analysis was conducted with 1-h intervals for each trajectory using the NOAA Hybrid Single-Particle Lagrangian Integrated Trajectory model (HYSPLIT, version 4) with meteorological field data (GDAS1) [28]. A residence time analysis (RTA) method was used to infer the dominant region where air mass passed over, affecting a receptor site. The air mass trajectory consisted of 48 endpoints. The RTA value for each grid cell $\left(0.2^{\circ}\right.$ latitude $\times 0.2^{\circ}$ longitude $)$ was calculated using the number of endpoints passing over the grid cell (i.e., the number of endpoints is the residence time of the air mass in each grid cell). Additionally, a PSCF method was applied to find the source regions of the chemical constituents in $\mathrm{PM}_{1}$ [29-31] (i.e., elevated concentrations of chemical constituents at a receptor site can be related to the air mass trajectory). The PSCF value for each grid cell was calculated using the ratio of the number of endpoints passing over the grid cell when the concentration of specific chemical constituents was within the upper 35\% level to the total number of endpoints passing over the grid. A weight function was applied to place less weight on the cells with a low number of endpoints. Furthermore, aerosol optical thickness (AOT) data were obtained from MODIS sensors aboard the Aqua and Terra satellites [32].

\section{Results and Discussion}

Figure 2a shows the time series of meteorological data (wind speed, wind direction, $\mathrm{RH}$, precipitation, solar radiation, and temperature) and concentration of gaseous species $\left(\mathrm{CO}, \mathrm{O}_{3}, \mathrm{SO}_{2}\right.$, and $\mathrm{NO}_{2}$ ) during the sampling period. The average temperature and $\mathrm{RH}$ were $20.6^{\circ} \mathrm{C}$ and $56.2 \%$, respectively. The average mixing ratio of $\mathrm{O}_{3}$ was $47.6 \mathrm{ppb}$, and $\mathrm{O}_{3}$ had a distinct diurnal pattern with correlations with temperature $(r=0.78)$ and solar radiation $(r=0.56)$. The average mixing ratios of $\mathrm{NO}_{2}$ and $\mathrm{SO}_{2}$ were $0.018 \mathrm{ppm}$ and $0.003 \mathrm{ppm}$, respectively. The elevated mixing ratio of $\mathrm{SO}_{2}$ was observed from 7 June 2015 to 8 June 2015 and 10 June 2015 to 11 June 2015.

Temporal variations of $\mathrm{PM}_{2.5}, \mathrm{PM}_{1}$, and the number size distribution are shown in Figure $2 \mathrm{~b}$. The $\mathrm{PM}_{1}$ was calculated as the summation of organics, nitrate, sulfate, ammonium, chloride, and $\mathrm{BC}$ concentrations. In addition to the measured chemical constituents (organics, nitrate, sulfate, ammonium, chloride, and $\mathrm{BC}$ ), other chemical components from dust and sea salts may exist, although their contribution to $\mathrm{PM}_{1}$ should be small. The average mass concentrations of $\mathrm{PM}_{2.5}$ and $\mathrm{PM}_{1}$ were $30.3 \pm 13.5 \mu \mathrm{g} / \mathrm{m}^{3}$ and $20.8 \pm 10.9 \mu \mathrm{g} / \mathrm{m}^{3}$, respectively, as indicated in Table 2. The $\mathrm{PM}_{1}$ explained approximately $68.5 \%$ of $\mathrm{PM}_{2.5}$ with a correlation coefficient of 0.70 between $\mathrm{PM}_{1}$ and $\mathrm{PM}_{2.5}$. The maximum concentrations of $\mathrm{PM}_{2.5}$ and $\mathrm{PM}_{1}$ were 101.0 and $77.1 \mu \mathrm{g} / \mathrm{m}^{3}$, respectively. The daily $\mathrm{PM}_{2.5}$ level was higher than the WHO standard value $\left(25 \mu \mathrm{g} / \mathrm{m}^{3}\right)$ on 17 days out of 28 days. One strong $\mathrm{PM}_{1}$ event where daily average $\mathrm{PM}_{1}$ was higher than $30 \mu \mathrm{g} / \mathrm{m}^{3}$ was found during 11 June 2015 to 13 June 2015. $\mathrm{PM}_{1}$ increased more than 2.1 times when compared to the average concentration during the whole sampling period. More on the characteristics of the $\mathrm{PM}_{1}$ event will be discussed later. The organics were the most dominant species in $\mathrm{PM}_{1}$. The average mass concentrations of organics, 
sulfate, nitrate, ammonium, and BC were $9.1 \mu \mathrm{g} / \mathrm{m}^{3}, 4.7 \mu \mathrm{g} / \mathrm{m}^{3}, 3.2 \mu \mathrm{g} / \mathrm{m}^{3}, 2.6 \mu \mathrm{g} / \mathrm{m}^{3}$, and $1.3 \mu \mathrm{g} / \mathrm{m}^{3}$, and their fractions in $\mathrm{PM}_{1}$ were $43.7 \%, 22.5 \%, 15.4 \%, 12.6 \%$, and $6 \%$, respectively. The fractions were similar to those at other urban sites [33] and at the same sampling site in 2011, 2012, and 2013 [8,13,17].

As shown in Figure 2b, nine NPF events were found in 28 measurement days. The NPF event here was defined when the number of particles less than $50 \mathrm{~nm}$ increased significantly with subsequent growth. The growth rate varied in the range of 7.2-11.0 nm/hour. The growth rate was calculated from the change of the mode diameter during particle growth time (the slope in the linear curve between the measured mode diameter and time represents the growth rate) $[6,15,34]$. The number concentration of particles was not correlated to the $\mathrm{PM}_{2.5}$ mass concentration. When the NPF event occurred, the mass concentration of pre-existing particles (i.e., $\mathrm{PM}_{2.5}$ ) was low, suggesting that the low surface area of pre-existing particles favored NPF. More discussion on NPF will be provided later.

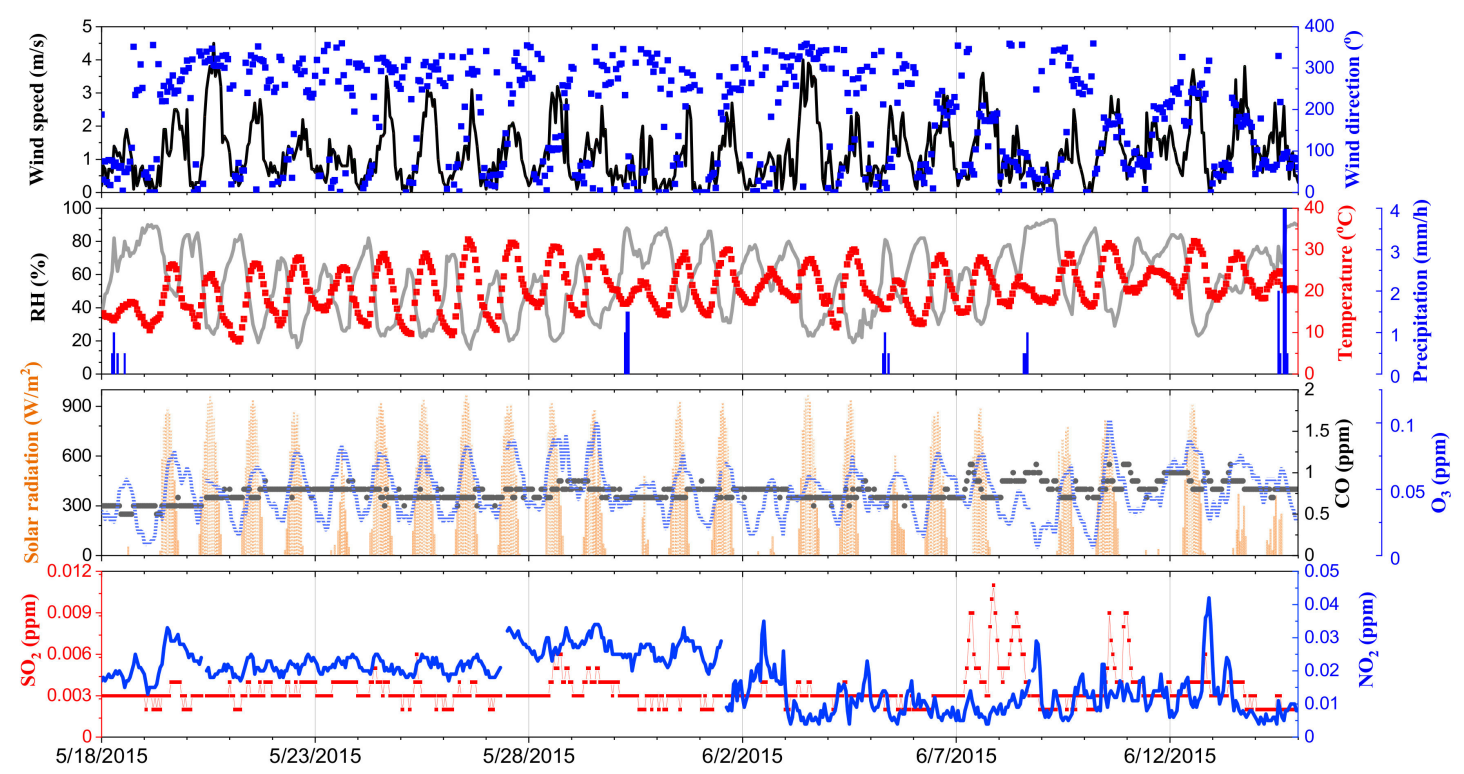

(a)

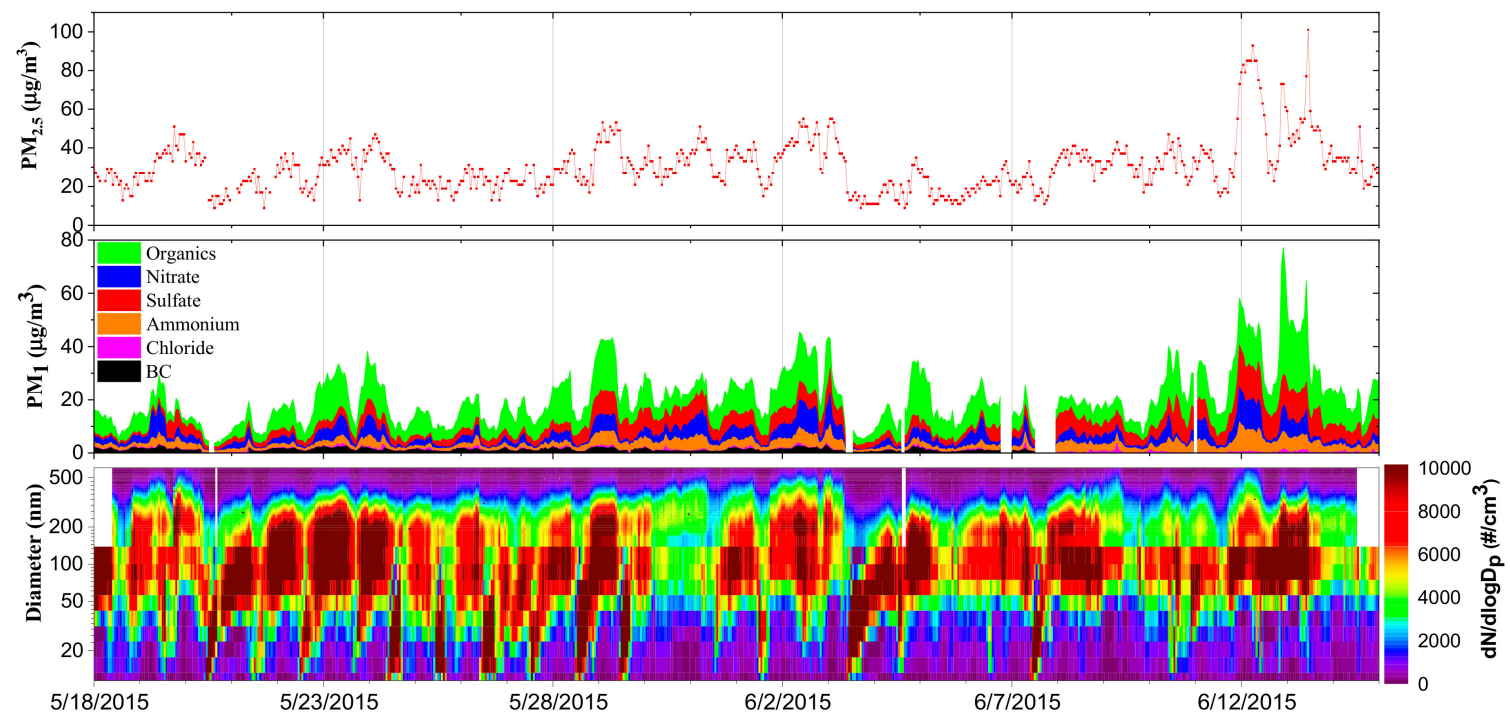

(b)

Figure 2. Time series of (a) meteorological data (wind speed, wind direction, $\mathrm{RH}$, precipitation, solar radiation, and temperature) and concentrations of gaseous species $\left(\mathrm{CO}, \mathrm{O}_{3}, \mathrm{NO}_{2}\right.$, and $\left.\mathrm{SO}_{2}\right)$, and (b) $\mathrm{PM}_{2.5}$ and $\mathrm{PM}_{1}$ mass concentrations, concentrations of organics, sulfate, nitrate, ammonium, chloride, $\mathrm{BC}$, and number size distribution. 
Table 2. Average values of the measured parameters during the whole sampling period and $\mathrm{PM}_{1}$ event.

\begin{tabular}{cccc}
\hline Measured Parameters & Unit & All Sampling Periods & PM $_{\mathbf{1}}$ Event \\
\hline $\mathrm{T}$ & ${ }^{\circ} \mathrm{C}$ & $20.5 \pm 5.47$ & $23.7 \pm 3.84$ \\
$\mathrm{RH}$ & $\%$ & $54.8 \pm 20.3$ & $58.2 \pm 18.3$ \\
Wind speed & $\mathrm{m} / \mathrm{s}$ & $1.2 \pm 0.87$ & $1.4 \pm 0.87$ \\
Solar radiation & $\mathrm{W} / \mathrm{m}^{2}$ & $334 \pm 336$ & $170 \pm 235$ \\
$\mathrm{O}_{3}$ & $\mathrm{ppb}$ & $47.6 \pm 18.8$ & $57.8 \pm 16.4$ \\
$\mathrm{NO}_{2}$ & $\mathrm{ppm}$ & $0.018 \pm 0.008$ & $0.015 \pm 0.009$ \\
$\mathrm{CO}$ & $\mathrm{ppm}$ & $0.76 \pm 0.11$ & $0.92 \pm 0.08$ \\
$\mathrm{SO}_{2}$ & $\mathrm{ppm}$ & $0.003 \pm 0.001$ & $0.004 \pm 0.001$ \\
$\mathrm{PM}_{2.5}$ & $\mu \mathrm{g} / \mathrm{m}^{3}$ & $30.3 \pm 13.5$ & $57.8 \pm 20.5$ \\
$\mathrm{PM}_{1}$ & $\mu \mathrm{m} / \mathrm{m}^{3}$ & $20.8 \pm 10.9$ & $43.3 \pm 12.9$ \\
$\mathrm{BC}$ & $\mu \mathrm{g} / \mathrm{m}^{3}$ & $1.3 \pm 0.6$ & $\mathrm{~N} / \mathrm{A}$ \\
$\mathrm{Ammonium}$ & $\mu \mathrm{g} / \mathrm{m}^{3}$ & $2.6 \pm 1.6$ & $5.8 \pm 2.0$ \\
Nitrate & $\mu \mathrm{g} / \mathrm{m}^{3}$ & $3.2 \pm 2.6$ & $6.4 \pm 3.9$ \\
Sulfate & $\mu \mathrm{g} / \mathrm{m}^{3}$ & $4.7 \pm 2.9$ & $11.1 \pm 2.03$ \\
Organics & $\mu \mathrm{m} / \mathrm{m}^{3}$ & $9.1 \pm 5.5$ & $19.4 \pm 8.83$ \\
$\mathrm{OOA}$ & $\mu \mathrm{g} / \mathrm{m}^{3}$ & $3.9 \pm 2.2$ & $9.0 \pm 2.5$ \\
$\mathrm{HOA}$ & $\mu \mathrm{mg} / \mathrm{m}^{3}$ & $4.4 \pm 3.2$ & $8.8 \pm 6.2$ \\
$\mathrm{~N}(10 \mathrm{~nm}-608 \mathrm{~nm})$ & $\mathrm{particles} / \mathrm{cm}^{3}$ & $6876 \pm 2827$ & $7624 \pm 2465$ \\
$\mathrm{~N}(650 \mathrm{~nm}-20 \mu \mathrm{m})$ & $\mathrm{particles} / \mathrm{cm}^{3}$ & $106 \pm 109$ & $322 \pm 264$ \\
\hline
\end{tabular}

To determine any relationship among the $\mathrm{PM}_{1}$ mass concentration, chemical constituents in $\mathrm{PM}_{1}$, and air mass, air mass backward trajectories $(48 \mathrm{~h}$ ) were clustered using the K-means algorithm [35]. As shown in Figure 3, five major clusters were found: Western (cluster 1), Northern (cluster 2), Northwestern (cluster 3), Southeastern (cluster 4), and Southwestern (cluster 5) trajectories explaining $15 \%, 13 \%, 34 \%, 23 \%$, and $14 \%$ of the total air masses, respectively. With cluster one, the highest $\mathrm{PM}_{1}$ $\left(28.6 \mathrm{\mu g} / \mathrm{m}^{3}\right)$ was found with dominating species of both organics $(41.9 \%)$ and sulfate $(24.4 \%)$. Cluster one passed over an industrial region in the Shandon Peninsula and the Yangtze River Delta (YRD) in China ( $\sim 664 \mathrm{~km}$ west of the site) where elevated $\mathrm{SO}_{2}$ emissions and AOT are often observed [36,37]. The $\mathrm{PM}_{2.5}$ mass concentration also showed a similar pattern to that of $\mathrm{PM}_{1}$, as shown in Figure 3 . With cluster four, which had the most stagnant air condition (the air mass speed was as low as $2.8 \mathrm{~km} / \mathrm{h}$ and the local wind speed was as low as $1.0 \mathrm{~m} / \mathrm{s}$ ), an elevated $\mathrm{PM}_{1}$ concentration was also observed. It is possible that the $\mathrm{PM}_{1}$ produced from local sources was not diluted efficiently at the stagnant condition, leading to the elevated $\mathrm{PM}_{1}$. Additionally, the cluster four air mass passed over a petrochemical industrial complex and steel works located $\sim 90 \mathrm{~km}$ Southeast of the site. Our data suggest that long-range transported aerosols and stagnant conditions played an important role in the increased $\mathrm{PM}_{1}$ and $\mathrm{PM}_{2.5}$ concentrations during the sampling period.
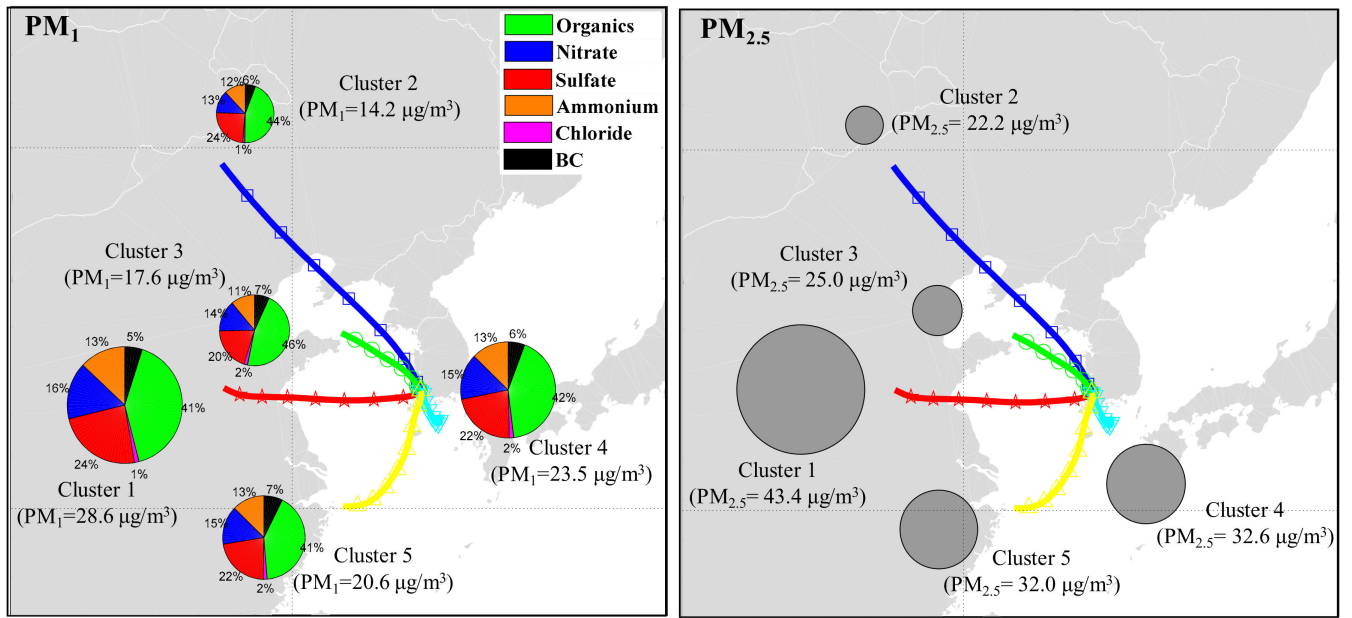

Figure 3. Concentrations of $\mathrm{PM}_{1}$ and $\mathrm{PM}_{2.5}$ with clustered air masses based on air mass backward trajectories $(48 \mathrm{~h})$. 
The PSCF results for sulfate, organics, and BC in $\mathrm{PM}_{1}$ are shown in Figure 4. Elevated mass concentrations of chemical constituents at a receptor site can be directly related to the air mass trajectory and source regions using the PSCF method. The potential source regions of sulfate were located in the South and East regions of China and South and East regions of Korea, suggesting that long-range transported aerosols played important roles in the elevated concentrations of sulfate at the sampling site. A lower number of source regions with a long distance were found for the elevated organics when compared to the sulfate. The potential source region for the BC was not clearly identified outside of Korea, suggesting that local sources may be responsible for the elevated $\mathrm{BC}$ concentration.
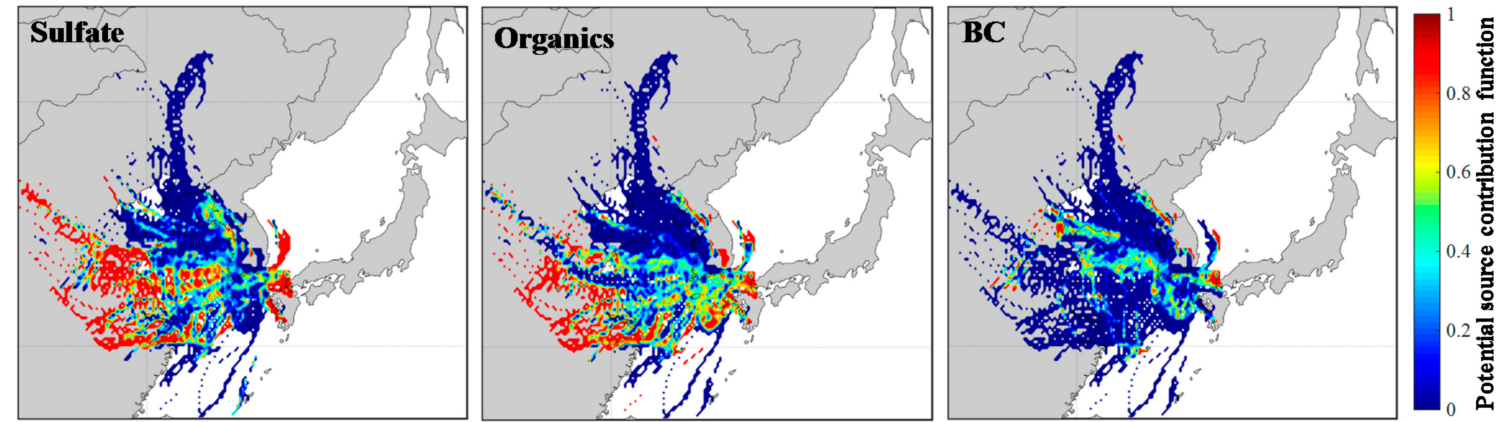

Figure 4. Potential source contribution function PSCF results for sulfate, organics, and BC.

The average diurnal variations of the chemical constituents in $\mathrm{PM}_{1}$ are shown in Figure 5a. Organics, nitrate, ammonium, chloride, and BC showed a similar diurnal pattern with increased concentrations in the morning and evening, and low concentrations in the afternoon. This behavior was related to the diurnal variation of mixing height, which led to changes in the wind speed and temperature, as shown in Figure 5b [38]. As the mixing layer increased in the afternoon, the concentrations of organics, nitrate, ammonium, chloride, and BC decreased significantly (i.e., the dilution effect). However, the OOAs decreased a little and sulfate increased, overcoming the mixing layer effect. This occurred as the strong photochemical activity in the afternoon led to the production of significant amounts of sulfate and OOAs.

During the $\mathrm{PM}_{1}$ event (significant increase in $\mathrm{PM}_{1}$ mass concentration) and NPF event (significant increase in the number concentration of submicrometer particles) days, the air mass retention times resulting from the RTA analysis were compared, as shown in Figure 6. During the $\mathrm{PM}_{1}$ event (11 June 2015 and 12 June 2015), the Western and Southwestern air mass influenced the site. Both sulfate and organics increased significantly during the $\mathrm{PM}_{1}$ event. Sulfate and organics were dominant on the first day of the $\mathrm{PM}_{1}$ event (11 June 2015), and organics became more dominant than sulfate on the second day (12 June 2015) with the change in air mass and wind direction as shown in Figure 6a. We believe that the high concentration of $\mathrm{PM}_{1}$ at the receptor site may be caused by long-range transported aerosols. The locations where the air mass passed over included major industrial complexes in China and Korea, possibly contributing to the elevated PM concentration. Satellite data from 12 June 2015 are shown in Figure 6b. The AOT was high in China (east region) and Korea (west region including the sampling site) when the $\mathrm{PM}_{1}$ event occurred. The AOT was determined from the extinction of light in the vertical column. Both ground and satellite data suggested that long-range transported aerosols played an important role in the elevated $\mathrm{PM}_{1}$. The number of particles in the larger size range $(650 \mathrm{~nm}-20 \mu \mathrm{m})$ increased significantly during the $\mathrm{PM}_{1}$ event, as shown in Table 2. 

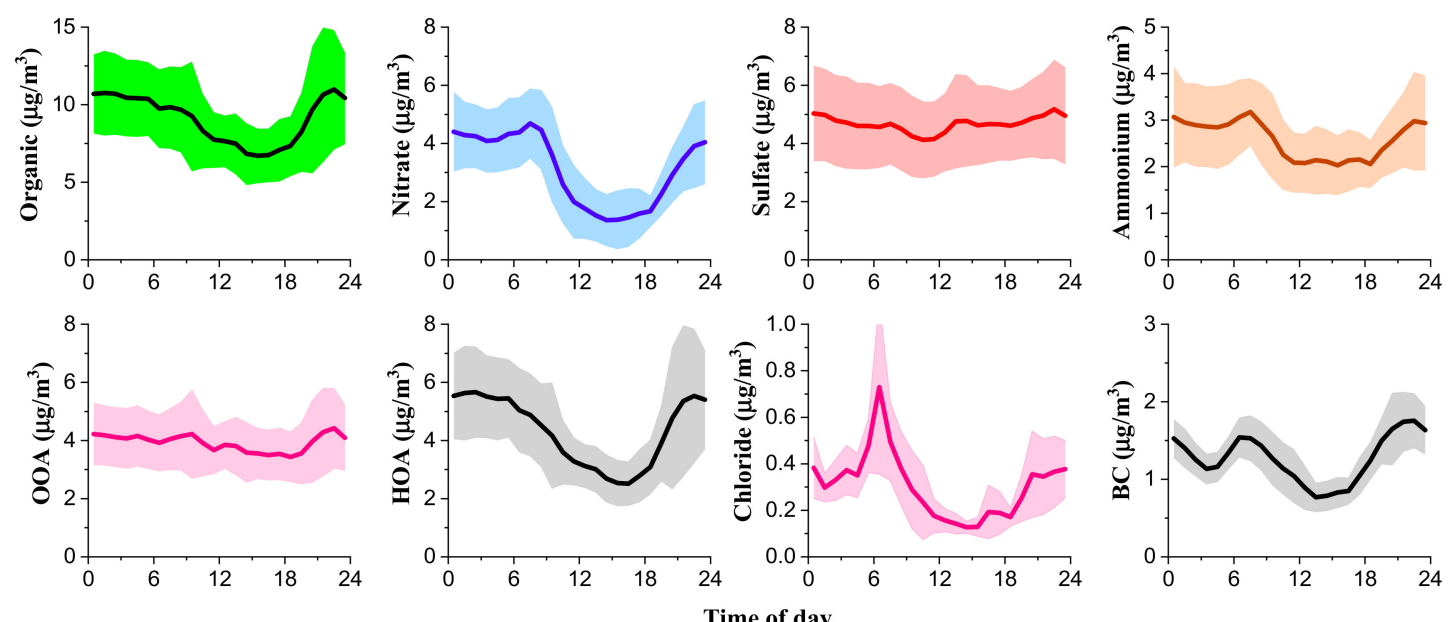

(a)
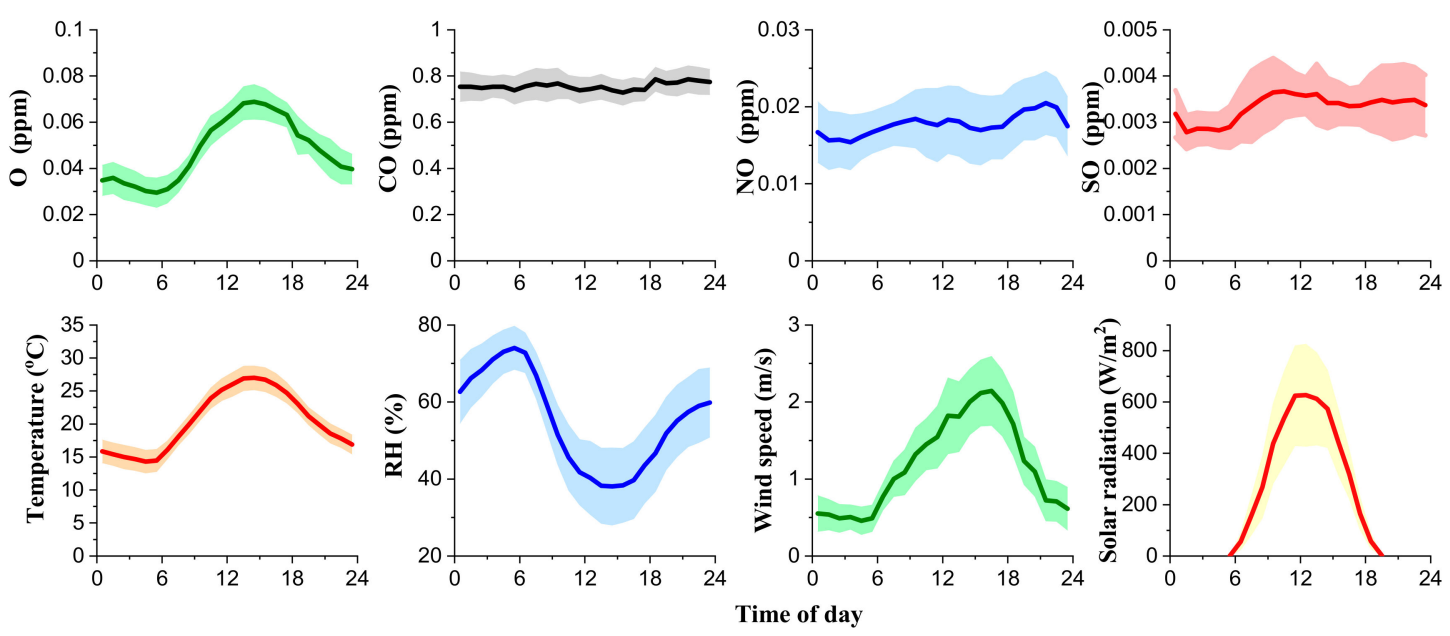

(b)

Figure 5. Diurnal variations of (a) organics, nitrate, sulfate, ammonium, OOA, HOA, chloride, and BC in $\mathrm{PM}_{1}$ and (b) gases and meteorological data. The solid line indicates the averaged value, and the shaded area represents the standard deviation.

Significantly different air masses were found during the NPF events. NPF events occurred when the Western air mass minimally influenced the site as shown in Figure 6a. The Western air mass was related to the elevated $\mathrm{PM}_{1}$ or $\mathrm{PM}_{2.5}$ mass concentration, providing a high surface area of pre-existing particles, which possibly led to suppressing the NPF [39]. The average surface area of particles during $\mathrm{PM}_{1}$ event days was $1007 \mu \mathrm{m}^{2} / \mathrm{cm}^{3}$. The surface area of particles during the NPF event was small as shown in Table S1 in the Supplementary Materials. During the NPF events, the time for the increased concentration of nanoparticles occurred from 10:00 to 14:00 with subsequent growth in the afternoon with strong solar radiation as shown in Figure 7 and Table S1 in the Supplementary Materials. Furthermore, this is consistent with the times for elevated sulfate and oxidized organics in submicrometer particles, as shown in Figure 7. Our data suggest that a low surface area of pre-existing particles and strong solar radiation favored NPF at the sampling site. Combustion can also contribute to the elevated number concentrations of particles less than $50 \mathrm{~nm}$. However, typical combustion particles did not show significant growth, as we observed here (banana shape in Figure 7). Furthermore, the concentration of $\mathrm{BC}$, one of the major combustion particles, did not increase significantly during NPF events. 

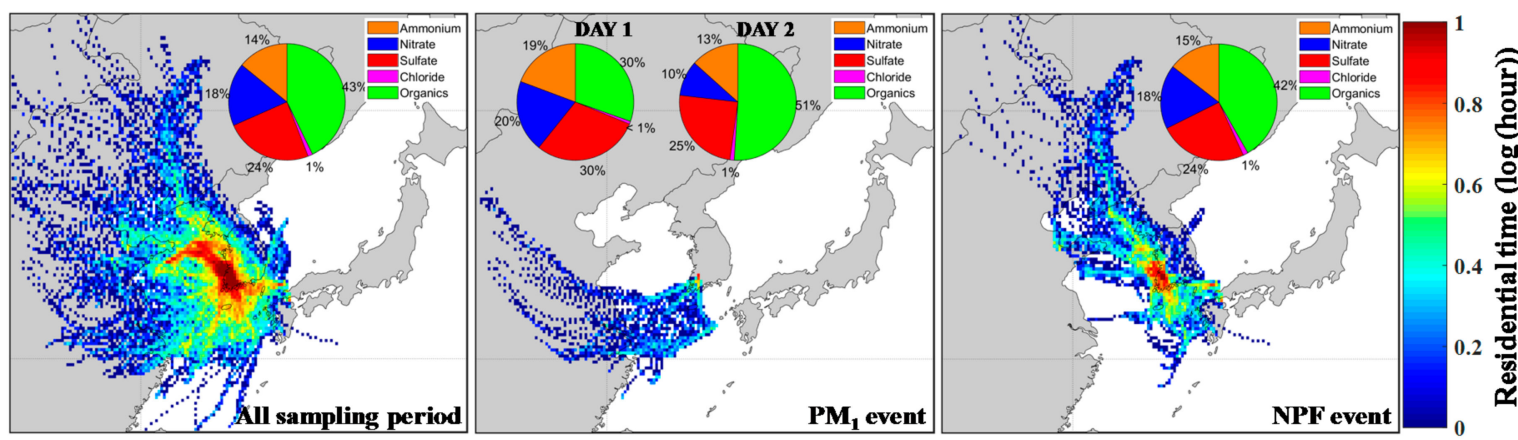

(a)

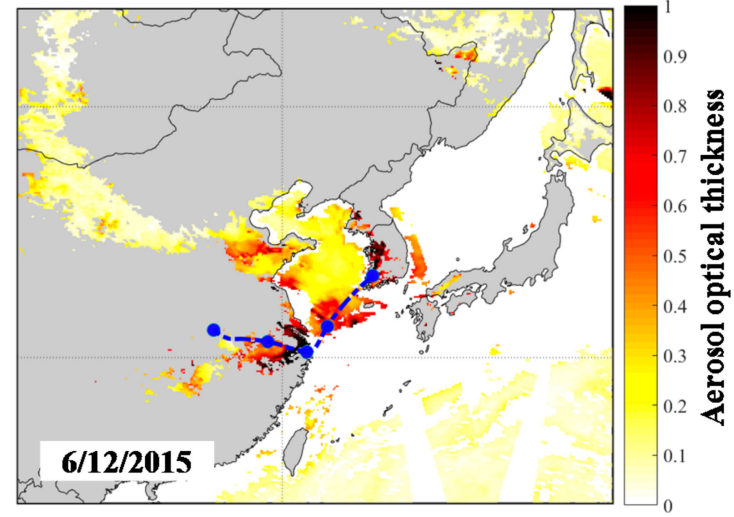

(b)

Figure 6. (a) Comparison of the residence times of air masses arriving at a receptor site during all sampling periods, the $\mathrm{PM}_{1}$ event, and NPF event, and (b) AOT data obtained from MODIS sensors aboard the Aqua and Terra satellites with air mass backward trajectory ( $48 \mathrm{~h}$ ) during the $\mathrm{PM}_{1}$ event (12 June 2015).

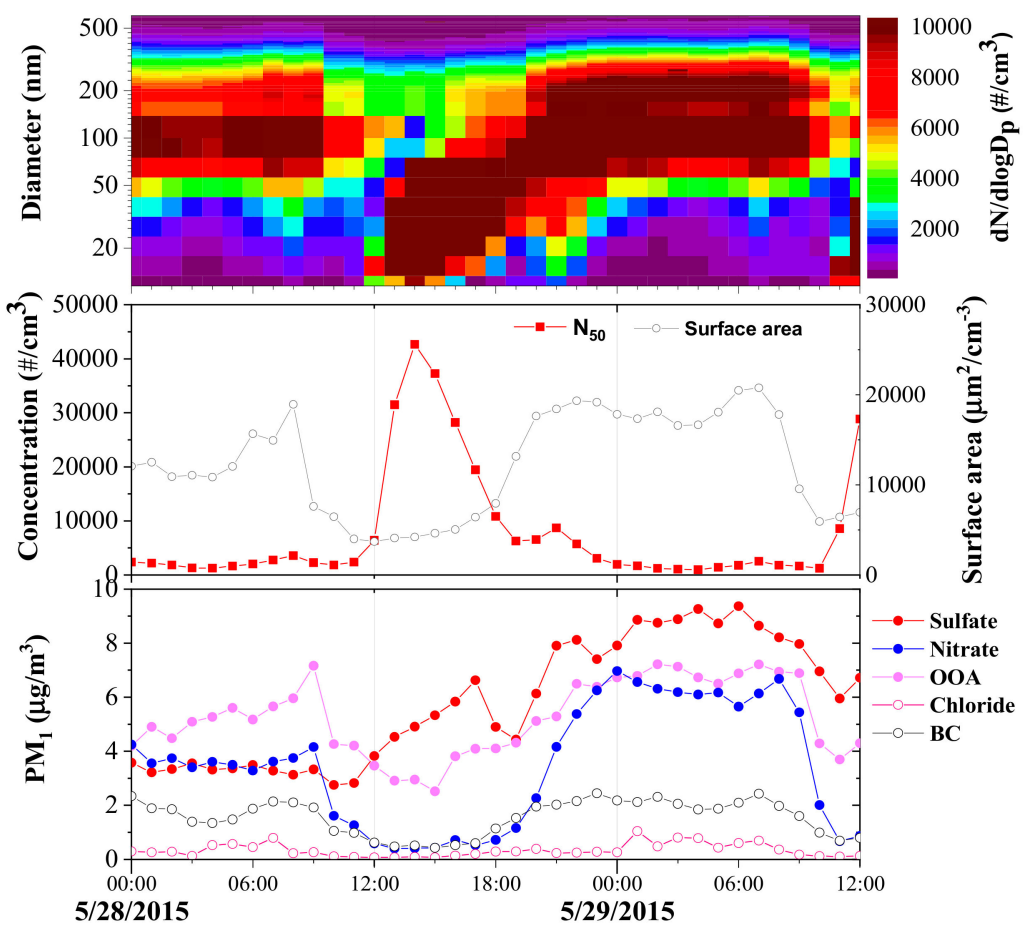

Figure 7. Variation of the number size distribution, $N(10-50 \mathrm{~nm})$, surface area, sulfate, OOAs, nitrate, chloride, and BC in $\mathrm{PM}_{1}$ during the NPF event day (28 May 2015). 


\section{Conclusions}

The chemical composition (organics, nitrate, sulfate, ammonium, chloride, and $\mathrm{BC}$ ) and number concentration of submicrometer particles were continuously measured to examine elevated mass $\left(\mathrm{PM}_{1}\right)$ and number concentrations during the MAPS-Seoul campaign. Organics $\left(9.1 \mu \mathrm{g} / \mathrm{m}^{3}\right)$ were found to be the most dominant species, followed by sulfate $\left(4.7 \mu \mathrm{g} / \mathrm{m}^{3}\right)$, nitrate $\left(3.2 \mu \mathrm{g} / \mathrm{m}^{3}\right)$, ammonium $\left(2.6 \mu \mathrm{g} / \mathrm{m}^{3}\right)$, and BC $\left(1.3 \mu \mathrm{g} / \mathrm{m}^{3}\right)$. Potential source regions of sulfate were located in the East and Southeast regions of China (West and Southwest of the site) and South and Southeast regions of Korea (south and southeast of the site). Local sources may be more responsible for the elevated $\mathrm{BC}$ concentration. One $\mathrm{PM}_{1}$ event and nine NPF events were observed during the campaign. Both sulfate and organics increased significantly in the $\mathrm{PM}_{1}$ event. Long-range transported aerosols and stagnant meteorological conditions played an important role in the elevated mass concentration of submicrometer particles ( $\mathrm{PM}_{1}$ event). The locations where the air mass passed over included major industrial complexes in China and Korea, possibly contributing to the elevated PM concentration. NPF started in the late morning and noon, and the newly-formed nanoparticles experienced gradual growth in the afternoon with growth rates of $7.2-11.0 \mathrm{~nm} / \mathrm{h}$, suggesting that these particles were produced by photochemical activity. A low surface area of pre-existing particles and strong solar radiation favored the NPF events observed in this study. Diurnal variation of the chemical constituents in $\mathrm{PM}_{1}$ suggested that sulfate and oxidized organics may be involved in nanoparticle formation and growth.

Supplementary Materials: The following are available online at http:/ / www.mdpi.com/2073-4433/9/10/393/s1, Table S1: Comparison of average parameters before, during, and after NPF events.

Author Contributions: K.P. designed the study, H.J.C., A.S., D.K., M.P., and H.J. carried out the field campaign for aerosol measurements. H.J.C. and J.K. analyzed measurement data.

Funding: This work was supported by the National Research Foundation of Korea (Grants NRF-2016R1A2A1A05005532, NRF-2016M1A5A1901779, and NRF-2017M3D8A1092220) funded by the Ministry of Science and ICT, and the National Research Foundation (NRF) of Korea.

Conflicts of Interest: The authors declare no conflict of interest.

\section{References}

1. IPCC. Climate Change 2013: The Physical Science Basis. Contribution of Working Group I to the Fifth Assessment Report of the Intergovernmental Panel on Climate Change; Cambridge University Press: Cambridge, UK, 2013.

2. Pope, C.A.; Dockery, D.W. Health Effects of Fine Particulate Air Pollution: Lines That Connect. J. Air Waste Manag. 2006, 56, 709-742. [CrossRef]

3. Cassee, F.R.; Heroux, M.E.; Gerlofs-Nijland, M.E.; Kelly, F.J. Particulate Matter Beyond Mass: Recent Health Evidence on the Role of Fractions, Chemical Constituents and Sources of Emission. Inhal. Toxicol. 2013, 25, 802-812. [CrossRef] [PubMed]

4. Pöschl, U. Atmospheric Aerosols: Composition, Transformation, Climate and Health Effects. Angew. Chem. Int. Ed. 2005, 44, 7520-7540. [CrossRef] [PubMed]

5. Park, K.; Park, J.Y.; Kwak, J.-H.; Cho, G.N.; Kim, J.-S. Seasonal and Diurnal Variations of Ultrafine Particle Concentration in Urban Gwangju, Korea: Observation of Ultrafine Particle Events. Atmos. Environ. 2008, 42, 788-799. [CrossRef]

6. Maskey, S.; Kim, J.S.; Cho, H.J.; Park, K. Ultrafine Particle Events in the Ambient Atmosphere in Korea. Asian J. Atmos. Environ. 2012, 6, 288-303. [CrossRef]

7. Guo, S.; Hu, M.; Zamora, M.L.; Peng, J.; Shang, D.; Zheng, J.; Du, Z.; Wu, Z.; Shao, M.; Zeng, L.; et al. Elucidating Severe Urban Haze Formation in China. Proc. Natl. Acad. Sci. USA 2014, 111, 17373-17378. [CrossRef] [PubMed]

8. Lee, K.; Park, J.; Kang, M.; Kim, D.; Batmunkh, T.; Bae, M.-S.; Park, K. Chemical Characteristics of Aerosols in Coastal and Urban Ambient Atmospheres. Aerosol Air Qual. Res. 2017, 17, 908-919. [CrossRef]

9. Jung, J.; Kim, Y.J. Tracking Sources of Severe Haze Episodes and Their Physicochemical and Hygroscopic Properties under Asian Continental Outflow: Long-Range Transport Pollution, Postharvest Biomass Burning, and Asian Dust. J. Geophys. Res. Atmos. 2011, 116, D02206. [CrossRef] 
10. Jung, J.; Lee, K.; Cayetano, M.G.; Batmunkh, T.; Kim, Y.J. Optical and Hygroscopic Properties of Long-Range Transported Haze Plumes Observed at Deokjeok Island Off the West Coast of the Korean Peninsula under the Asian Continental Outflows. J. Geophys. Res. Atmos. 2015, 120, 8861-8877. [CrossRef]

11. Wang, Z.; Wu, Z.; Yue, D.; Shang, D.; Guo, S.; Sun, J.; Ding, A.; Wang, L.; Jiang, J.; Guo, H.; et al. New Particle Formation in China: Current Knowledge and Further Directions. Sci. Total Environ. 2017, 577, 258-266. [CrossRef] [PubMed]

12. Yu, H.; Ren, L.; Kanawade, V.P. New Particle Formation and Growth Mechanisms in Highly Polluted Environments. Curr. Pollut. Rep. 2017, 245-253. [CrossRef]

13. Park, J.; Lee, S.; Kang, M.; Cho, H.J.; Lee, K.; Park, K. Seasonal Characteristics of Submicrometer Organic Aerosols in Urban Gwangju, Korea Using an Aerosol Mass Spectrometer. Atmos. Environ. 2013, 80, 445-454. [CrossRef]

14. Merikanto, J.; Spracklen, D.V.; Mann, G.W.; Pickering, S.J.; Carslaw, K.S. Impact of Nucleation on Global Ccn. Atmos. Chem. Phys. 2009, 9, 8601-8616. [CrossRef]

15. Kulmala, M.; Vehkamäki, H.; Petäjä, T.; Dal Maso, M.; Lauri, A.; Kerminen, V.M.; Birmili, W.; McMurry, P.H. Formation and Growth Rates of Ultrafine Atmospheric Particles: A Review of Observations. J. Aerosol Sci. 2004, 35, 143-176. [CrossRef]

16. McMurry, P.H.; Fink, M.; Sakurai, H.; Stolzenburg, M.R.; Mauldin, R.L.; Smith, J.; Eisele, F.; Moore, K.; Sjostedt, S.; Tanner, D.; et al. A Criterion for New Particle Formation in the Sulfur-Rich Atlanta Atmosphere. J. Geophys. Res. 2005, 110, D22S02. [CrossRef]

17. Park, K.; Park, J.; Lee, S.; Cho, H.J.; Kang, M. Real Time Measurement of Chemical Composition of Submicrometer Aerosols at Urban Gwangju in Korea by Aerosol Mass Spectrometer. Atmos. Enviro. 2012, 62, 281-290. [CrossRef]

18. Jayne, J.T.; Leard, D.C.; Zhang, X.; Davidovits, P.; Smith, K.A.; Kolb, C.E.; Worsnop, D.R. Development of an Aerosol Mass Spectrometer for Size and Composition Analysis of Submicron Particles. Aerosol Sci. Technol. 2000, 33, 49-70. [CrossRef]

19. Allan, J.D.; Jimenez, J.L.; Williams, P.I.; Alfarra, M.R.; Bower, K.N.; Jayne, J.T.; Coe, H.; Worsnop, D.R. Quantitative Sampling Using an Aerodyne Aerosol Mass Spectrometer 1. Techniques of Data Interpretation and Error Analysis. J. Geophys. Res. Atmos. 2003, 108. [CrossRef]

20. Takegawa, N.; Miyazaki, Y.; Kondo, Y.; Komazaki, Y.; Miyakawa, T.; Jimenez, J.L.; Jayne, J.T.; Worsnop, D.R.; Allan, J.D.; Weber, R.J. Characterization of an Aerodyne Aerosol Mass Spectrometer (Ams): Intercomparison with Other Aerosol Instruments. Aerosol Sci. Technol. 2005, 39, 760-770. [CrossRef]

21. Jimenez, J.L.; Jayne, J.T.; Shi, Q.; Kolb, C.E.; Worsnop, D.R.; Yourshaw, I.; Seinfeld, J.H.; Flagan, R.C.; Zhang, X.; Smith, K.A. Ambient Aerosol Sampling Using the Aerodyne Aerosol Mass Spectrometer. J. Geophys. Res. Atmos. 2003, 108. [CrossRef]

22. Ulbrich, I.; Canagaratna, M.; Zhang, Q.; Worsnop, D.; Jimenez, J. Interpretation of Organic Components from Positive Matrix Factorization of Aerosol Mass Spectrometric Data. Atmos. Chem. Phys. 2009, 9, 2891-2918. [CrossRef]

23. Ng, N.; Canagaratna, M.; Jimenez, J.; Zhang, Q.; Ulbrich, I.; Worsnop, D. Real-Time Methods for Estimating Organic Component Mass Concentrations from Aerosol Mass Spectrometer Data. Environ. Sci. Technol. 2010, 45, 910-916. [CrossRef] [PubMed]

24. Zhang, Q.; Jimenez, J.L.; Canagaratna, M.R.; Ulbrich, I.M.; Ng, N.L.; Worsnop, D.R.; Sun, Y. Understanding Atmospheric Organic Aerosols Via Factor Analysis of Aerosol Mass Spectrometry: A Review. Anal. Bioanal. Chem. 2011, 401, 3045-3067. [CrossRef] [PubMed]

25. Hansen, A.; Rosen, H.; Novakov, T. The Aethalometer-an Instrument for the Real-Time Measurement of Optical Absorption by Aerosol Particles. Sci. Total Environ. 1984, 36, 191-196. [CrossRef]

26. Cheng, Y.-H.; Lin, M.-H. Real-Time Performance of the Microaeth ${ }^{\circledR}$ Ae51 and the Effects of Aerosol Loading on Its Measurement Results at a Traffic Site. Aerosol Air Qual. Res. 2013, 13, 1853-1863. [CrossRef]

27. Hinds, W.C. Aerosol Technology: Properties Behavior, and Measurement of airborne Particles, 2nd ed.; John Wiley \& Sons: Toronto, ON, Canada, 1999.

28. Air Resources Laboratory. Real-Time Environmental Applications and Display System. Available online: http:/ / ready.arl.noaa.gov (accessed on 30 January 2018).

29. Ashbaugh, L.L.; Malm, W.C.; Sadeh, W.Z. A Residence Time Probability Analysis of Sulfur Concentrations at Grand Canyon National Park. Atmos. Environ. (1967) 1985, 19, 1263-1270. [CrossRef] 
30. Ara Begum, B.; Kim, E.; Jeong, C.-H.; Lee, D.-W.; Hopke, P.K. Evaluation of the Potential Source Contribution Function Using the 2002 Quebec Forest Fire Episode. Atmos. Environ. 2005, 39, 3719-3724. [CrossRef]

31. Kim, I.S.; Wee, D.; Kim, Y.P.; Lee, J.Y. Development and Application of Three-Dimensional Potential Source Contribution Function (3d-Pscf). Environ. Sci. Pollut. Res. Int. 2016, 23, 16946-16954. [CrossRef] [PubMed]

32. NASA Earth Observations. Available online: https://neo.sci.gsfc.nasa.gov (accessed on 30 January 2018).

33. Jimenez, J.; Canagaratna, M.; Donahue, N.; Prevot, A.; Zhang, Q.; Kroll, J.; DeCarlo, P.; Allan, J.; Coe, H.; $\mathrm{Ng}$, N. Evolution of Organic Aerosols in the Atmosphere. Science 2009, 326, 1525-1529. [CrossRef] [PubMed]

34. Dal Maso, M.; Kulmala, M.; Riipinen, I.; Wagner, R.; Hussein, T.; Aalto, P.P.; Lehtinen, K.E. Formation and Growth of Fresh Atmospheric Aerosols: Eight Years of Aerosol Size Distribution Data from Smear Ii, Hyytiala, Finland. Boreal Environ. Res. 2005, 10, 323.

35. He, Z.; Kim, Y.J.; Ogunjobi, K.O.; Hong, C.S. Characteristics of Pm2.5 Species and Long-Range Transport of Air Masses at Taean Background Station, South Korea. Atmos. Environ. 2003, 37, 219-230. [CrossRef]

36. Huang, R.J.; Zhang, Y.; Bozzetti, C.; Ho, K.F.; Cao, J.J.; Han, Y.; Daellenbach, K.R.; Slowik, J.G.; Platt, S.M.; Canonaco, F.; et al. High Secondary Aerosol Contribution to Particulate Pollution During Haze Events in China. Nature 2014, 514, 218-222. [CrossRef] [PubMed]

37. Xie, X.; Liu, X.; Wang, H.; Wang, Z. Effects of Aerosols on Radiative Forcing and Climate over East Asia with Different So2 Emissions. Atmosphere 2016, 7, 99. [CrossRef]

38. Wallace, J.M.; Hobbs, P.V. Atmospheric Science: An Introductory Survey; Elsevier: San Diego, CA, USA, 2006; Volume 92.

39. Cai, R.; Yang, D.; Fu, Y.; Wang, X.; Li, X.; Ma, Y.; Hao, J.; Zheng, J.; Jiang, J. Aerosol surface area concentration: A governing factor in new particle formation in Beijing. Atmos. Chem. Phys. 2017, 17, 12327-12340. [CrossRef]

(C) 2018 by the authors. Licensee MDPI, Basel, Switzerland. This article is an open access article distributed under the terms and conditions of the Creative Commons Attribution (CC BY) license (http:/ / creativecommons.org/licenses/by/4.0/). 